[8] Afthot, K.D., Auriol, E., Barkits, R, and Manapo, M. 1995. A Review of Induzrial Case-Bresd Rezoching Tools Oxfond Al inteligence.

[9] ANowE 1996. ISAC: A CBR SYSTIM Fok Deczion SUPPORT IN AIR TRAFIC CONTROL LeCTUPE NOTES IN ARTIFICUL.

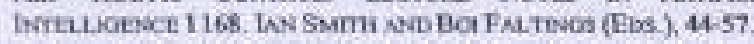

(10) Branting $K$ and Ah, D 1995 Stratified Cane-Brod Reasneing: Reusine Hierurchical Problem Solving Episodes, Proceeding of the

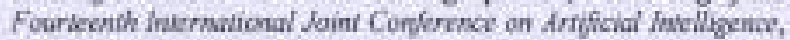
Mantreal, Cands, 20-25.

[11] Brestaw L, und A.a D, 1906. Simplifying Decision Troes: A Sarty. Washington, DC: Naval Research Laboratory, Navy Censer for Applied Restarch in Artificial Imsllipance.

[12] Carbonell, 1. 1983. Learning by hnabey. Formulating and Generiliring Plans from Past Experience. Mnchine Learning, 2

[13] Chestiem, W and Craf, I 1997, Case-Bssed Reasoning in Color Matching Proc ICCAR-97. Leakc, D \& Plan, E (Eda) DNAI.

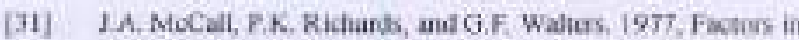
Software Qualify, Technifal Report RADC-TR-77-369, US Departmeat of commorce.

\title{
Pengukuran Indeks Kinerja Dosen dengan \\ Logika Fuzzy
}

Springer

[14] Doyle M. Hayes, C. Curninghan, P. and Smith, B. 1998. CBR Net ismain Technology over i Network. Department of Computer Seitence, Trinity College Dublin.

[15] Doyle, M., Cusningham, C. 1999. On Balancing Cient-Server Load in fatelligent Web-hroed Applications Involvisg Dialog TCD-CS. $1999-25$.

f16] Hammond, K. 1989. On Fuactianally Motivated Vecalibuaries; An Apotogia. Procendires of the Second Wankshop on Case-Based Reasoning. FL USA.

[17] Heanessy, D and Hinkie D. 1992, Applying Case Based Reasoning to Aubodave Lobling IEEE Expert, 7, 2t-27?

[I8] Hunter J. and Grawford W. 1995. Javs Serviet Pragrumming. O'Reilly \& Associates Inc.

[19] Knapik, M and Juhnsan, J. 1998. Dereloping Intelligat Aeents for Distribsted Systems, McGiraw-Hin.

[20] Kolodner, J. 1993. Case-Basel Resweing Morgan Kexilmann Publishers, loc

[21] RESBDCK, C. ND SCHANK, R. 1989. RASIDE CNSE-BAsED REASCEING, L,AWEFECE ERBALM ASSOCLATES, INC

[22] Sanank, $R$, and Abelsun. 1977. Scripts, Plase, Goals and Understandisg, Hillsdale. NI: Lanreace frilbaum Acsaciates

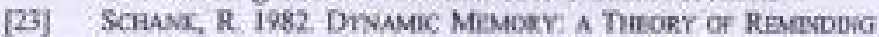

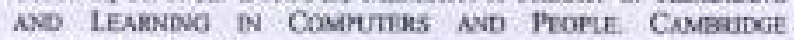
(fNIVIesitr Pross

[24] Watson, 1, 1905; An Introducation of Case-Based Reasoniz, Lectare Notes in Artifictal Intelligence 1020 Progress in Cise-finovd Reasonag in D. Watson (ed ). Springer.

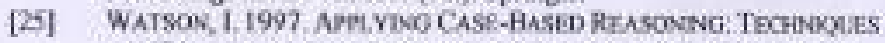

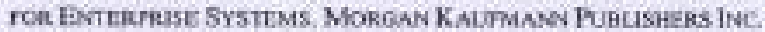

[26] Wasson, 1 \& Gardingen, D. 1999, A Distributed Cise-Based Reasoning Application for Enginecring Sales Surpont. Pracredong

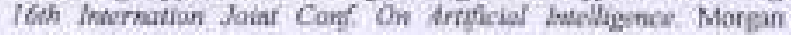
Kautmann Nablisters lac.

1271 Qiang Yanz Edward Kim and Kirsa Racinc 1992. CascAdvison Sepporting lateraetive Problem Solving and Cave Hase Maintenance for Help Desk Applicutions. LCCAr97 Workiniog ow Practical User of CBA. Nogopa. Aapm.

Nonaka, 1, and H. Tabeuchi. 1995. The kacumbdy-

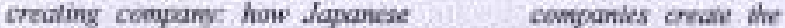
donamior of intorarion New York, NY: Onsurd University

[29] Davenport. T.H. 1903. Process invowation mengrwering work throwxh Infarnoutson fectinobove. Boston, MA. Plavard Business School Press

[30] Devenport, TH D.W de Lang and MC. Beers. 1998. Successful

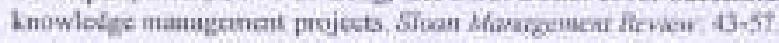

\begin{abstract}
Abstrak -Kualitas pendidikan merupakan suatu yang penting, salah satu faktar yang mempengaruhi kualitas pendidikan adaloh pengajar. Dalam pendidikan tingggi, pengajaridosen meniegang peranan yang penting dalam kualitas luiusan. Untuk meningkatkan kualitas lulusan diperlukan dosen yang berkualitas, baik dalam hal penguasam materi maupan aspek pembelajaran lainnya. Salah sanu cara untuk mengetahui kualitas dosen dalam proses belajar mengajar yaitu dengan melakukan evahuasi kinerja terhadap dosen yang dilakwkan oleh mahasiswa. dengan menggunakan kuisioner yang didalammya terdapat beberapa aspek penilaian, antara lain penampilan fisik, makeriyung di sampaikan, disiplan dan perilaku
\end{abstract}

Pengolahan ferhadap hasil kaistaner ini secara sederhana dilakukan dengan menggunakan metode matematika biosa mengunakan numes nilai rata-rata. Hasil pengolahan ini kurang akurat, untuk its sntuk untuk meningkatkan akurasi pengolahan data ini digunakan metade fuszy. Metode ini digunakan karena fuszy dapat mengolah data yang samar dan Sehingga hasil pengolahan data dapar lebih akarat.

Keywords - dasen, kuivioner, fuzzy, kinerja dosen

\section{PENDAHULUAN}

Mentransformasikan, mengembangkan dan menyebarluaskan ilmu pengetahuan, teknologi dan seni melalui pendidikan, penelitian dan pengabdian kepada masyarakat merupakan tugas secorang dosen (Undang- 
Undang RI No.14 tentang Guru dan Dosen, 2005). Mengajar merupakan salah satu aktifitas dosen yang langsung berhubungan dengan mahasis'wa. Aktifitas belajar mengajar di perguruan tinggi tidak hanya memberikan materi, tetapi juga menumbuhkan sikap kreatif, inovalif, proaktif, serta mengembangkan poteasi mahasiswa juga membentuk pola fikir, bagi mahasiswa. Organisasi dan manajemen yang schat dan efektif serta didukung dosen yang profesional sangat menunjang mutu proses belajar mengajar, mutu lulusan dan mutu pelayanan Tri Dharma pada stakeholder (Kustono, 2010). Sehingga dapat meningkatkan nilai akreditasi perguruan tinggi tersebut. Dengan demikian proses belajar mengajar merupakan proses utama dalam suatu institusi pendidikan dan kualitas pengajar/dosen sangat penting untuk peningkatan kualitas institusi (Dong \& Dai, 2009).

Dengan kata lain evaluasi terhadap kualitas mengajar dapat meningkatkan antusias kinerja dosen serta meningkatkan manajemen dan kualitas pengajaran (XiuHong, GuiXiang, JunQing \& Lan, Nov 21-22, 2009). Evaluasi terhadap kinerja dosen ini dapat dilakukan dengan berbagai cara, diantaranya adalah dengan memberikan angket kuisioner kepada mahasiswa untuk menilai kualitas dosen yang mengajar suatu matakuliah. Mahasiswa diberikan kuisioner yang berisi point-point yang berkaitan dengan kompetensi, metode penyampaian, perencanaan, komunikasi, penampilan serta kedisiplinan. Cara ini merupakan salah satu cara yang efektif dan efisien karena inputan langsung dari mahasiswa yang bersangkutan yang mengalami dan merasakan proses belajar mengajar dengan dosen tersebut. Evaluasi ini dilaksanakan secera periodik artinya evaluasi dilakukan pada setiap kurun waktu yang tetap. Hal ini untuk menjaga akuntabilitas kepada pemangku kepentingan terkait dengan kinerja perguruan tinggi (Kustono, 2010). Kuisioner yang telah disi oleh mahasiswa selanjutnya diolah oleh staf akademik Pengolahan kuisioner ini dilakukan dengan melakukan pertitungan dengan metode matematika ratarata terhadap nilai-nilai bobot pada point-point evaluasi.

Ternyata pengolahan kuisioner evaluasi kinerja dosen ini memiliki beberapa masalah dan hal ini merupakan isu yang sulit dan sensitif yang memiliki aspek-aspek kuantitatif dan kualitatif, kompleksitas dan ketidaktepatan dan terdapat atribut yang cukup banyak serta hasil pengukurannya kabur (Neogi, Mondal, \& Mandal, 2008, 15 April)

Selama ini sistem penilaian yang sudah ada bersifat tertutup. Sehingga yang dinilai (dalam hal ini dosen), tidak dapat mengetalui secara pasti kriteria yang digunakan untuk proses penilaian sehingga hal tersebut mengakibatkan kecemburuan sosial antara pihak satu dengan pihak yang laimuat. Hal tersebut menjadi faktor pemicu tertudap memburuknya kinerja dosen den atau tanpa disadari oleh pihak manajerial.

Logika fuzzy mengevaluasi secara komprehen melalui analisis regresi dan multiple discriminan ana methods, dan mencapai beberapa hasil, tapi index pre dan metode evaluasi tidak tercapai dan sulit un menentukan bobot evaluasi (Dong \& Dai, 2009).

Pada penelitian ini pendekatan fuzzy akan diguna untuk mengevaluasi kinerja dosen. Studi kasus y diambil adalah evaluasi kinerja dosen dengan kuisic yang diisi oleh mahasiswa pada Universitas Ban Lampong

\section{MEtode PENELTTIAN}

\section{I Analisa Kebutuhan}

1. Kuisioner Evaluasi Kinerja Dosen Di FIK UBL

Dalam pengolahan kuisioner kinerja dosen pada $\mathrm{F}$ UBL masih menggunakan perhitungan matemat biasa, Apabila pengelolaannya masih menggunak cara perhitungan matematika biasa, tentu he keakuratanya tidak senkurat dengan menggunal metode tertentu (Fizzy). Untuk itu perlu adar perubahan sistem dari perhitung manual/matematika biasa dengan menggunak metode perhitungan fuzzy, sehingga menghasilk hasil perhitungan yang akurat sehingga da mendukung manajemen untuk penempatan kemt dosen pada mata kuliah tertentu.

\section{Wawancara}

Merupakan metode pengumpulan data dengan c mengajukan pertanyaan-pertanyaan atau jawal secara langsung kepada pihak tertentu dalam membantu pengumpulan data.

\section{Kepustakaan}

Untuk mendukung proses analisa ini pen melakukan pengumpulan data melalui buku-ba referensi dan literature lain. Metodo kepustak merupakan penelitian yang dilakukan dengan c mempelajari sumber-sumber tertulis, seperti bu buku, jurnal, dan bahan-bahan tertulis lainnya y berhubungan dengan pengetahuan teoritis mengs masalah yang diteliti, dibaca, dicatat, dipelajari s diresume untuk kemudian dijadikan data.

\subsection{Perancangan Penelitian}




\section{Use Case}

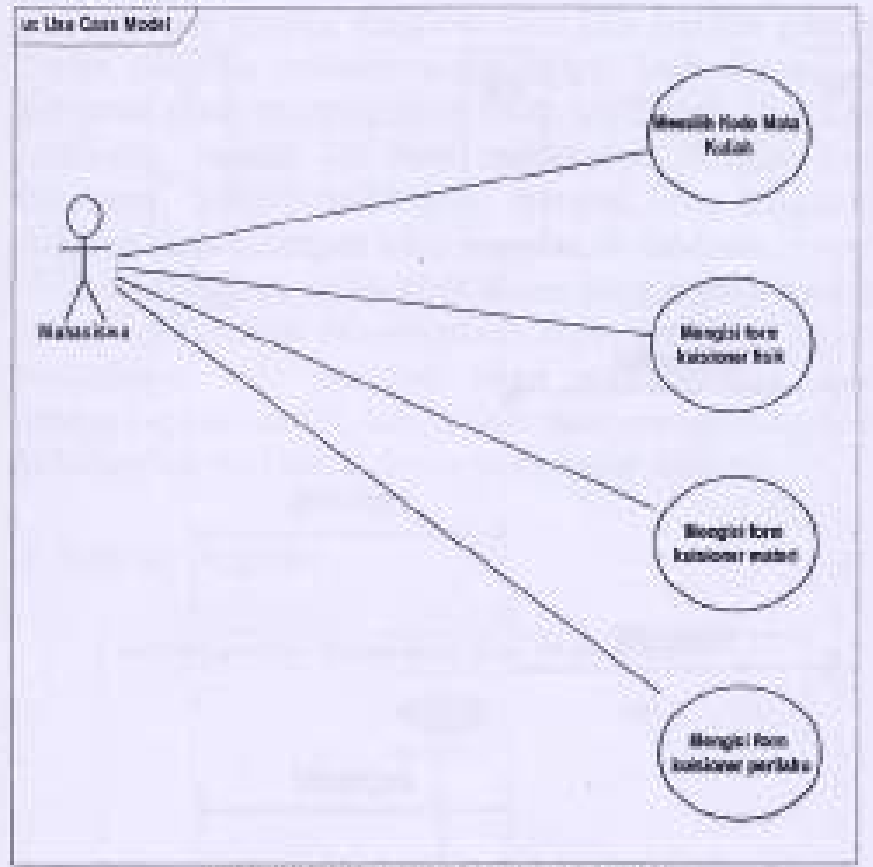

Gamber 1. Use Case Diagram Mahrsiswe

Dari gambar diatas dapat dilihat mahasiswa pertama kali memilih kode mata kuliah, kedua mengisi form kuisioner fisik, materi, dan perilaku. Setelah mengisi form kuisioner perilaku data yang mahasiswa telah isi akan di simpan di database.

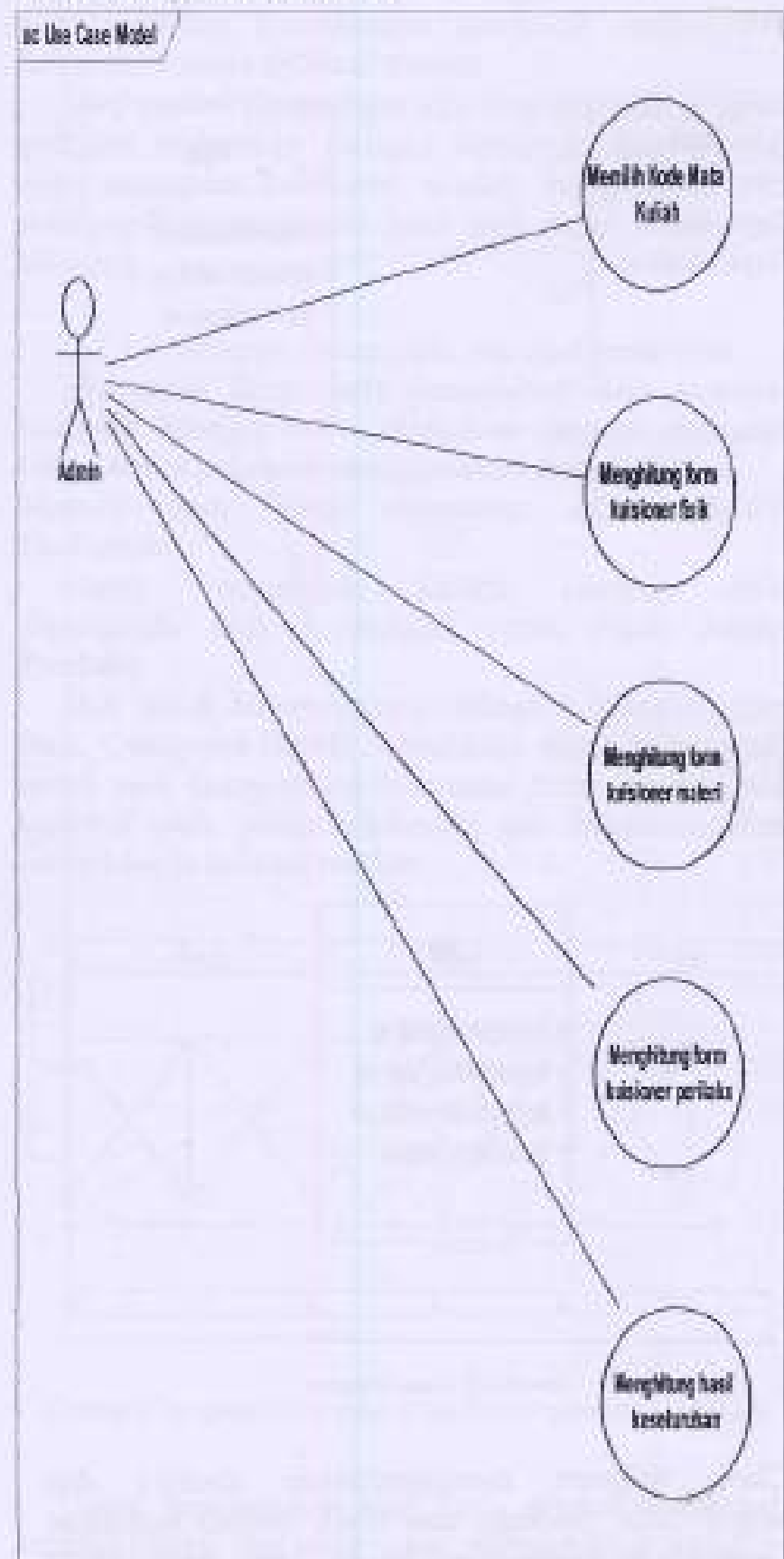

Ganbar 2, Use Case Diagran Adnin

Dari gambar diatas dapat kita lihat apa saja yang dilakukan admin untuk memproses kuisioner yang telah diisi oleh mahasiswa sebelumnya. Pertama admin memilih kode dosen mana yang ingin dihitung. menghitung form kuisioner fisik, materi dan perilaku, baru dihitung hasil kescluruhannya

\section{Class Diagram}




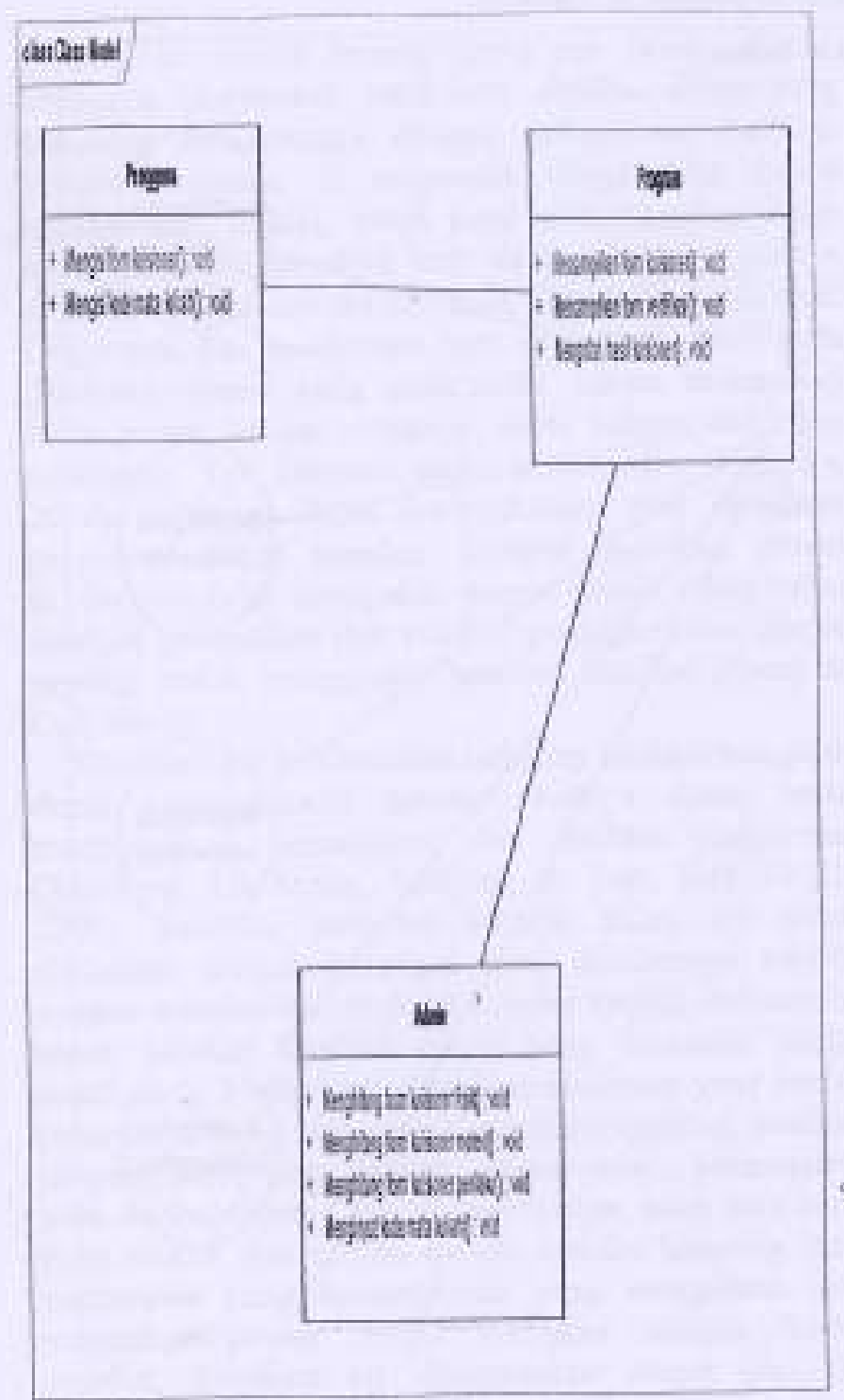

Gambar 3, Class Diveram

Class diagram menggambarkan struktur dan deskripsi class, package dan objek beserta hubungan satu sama lain. Pada penelitian ini dapat digambarkan class diagram sistem seperti diatas.

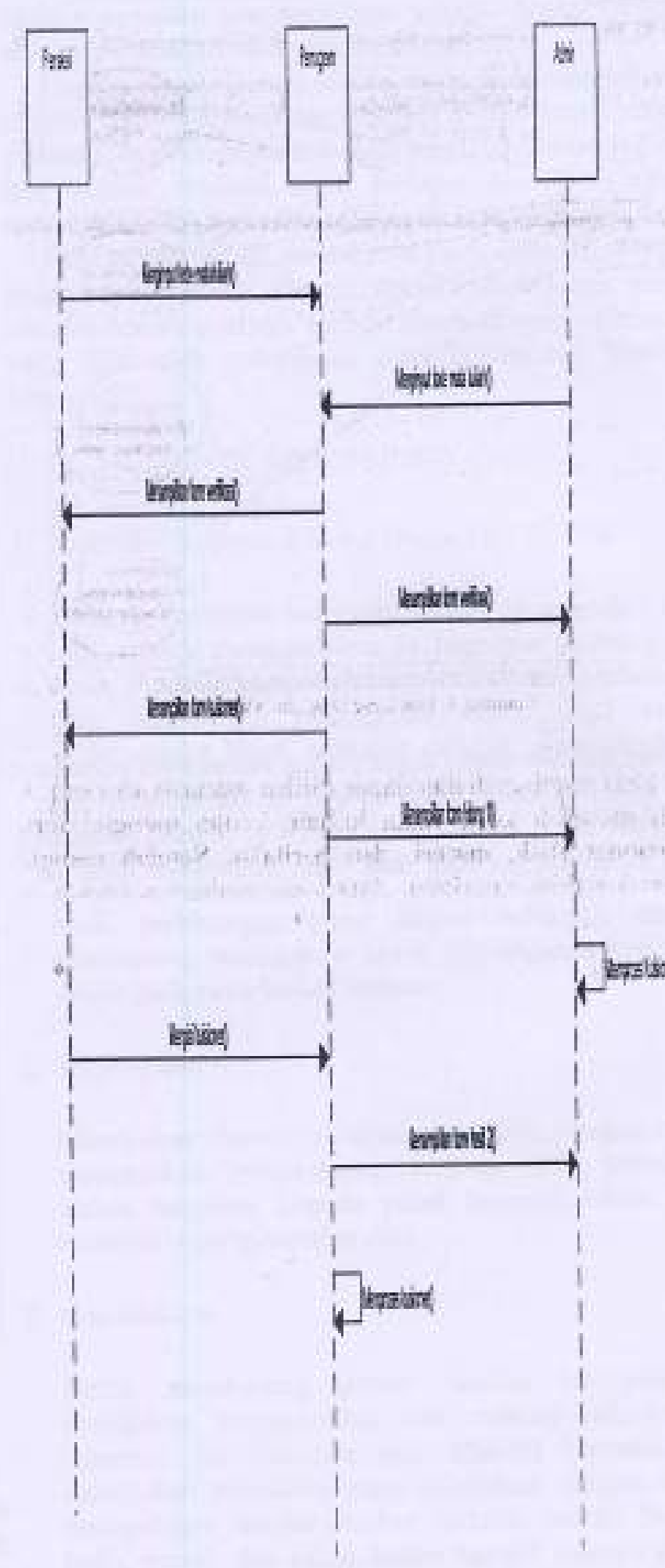

Ganhir 4. Sequence Diaym

Sequence diagram menggambarkan interaksi ar objek pada suatu sistem yang dikembangkan. Seque daggram memiliki dun dimensi utama yaitu dim 
vertikal yang menggambarkan objek-objek yang terkait pada masing-masing diagram. Jika kita melihat gambar diatas, pertama mahasiswa menginput kode dosen, lalu program akan menampilkan form verifikasi, dan form kuisioner, setelah itu baru mahasiswa mengisi form kuisioner. Setelah mahasiswa mengisi form kuisioner, datanya akan disimpan oleh program di datahase.

Admin juga memilih kode dosen yang ingin dithitung, lalu program akan menampilkan form verifikasi seperti mahasiswa, lalu program akan menampilkan form hitung kepada admin, lalu admin akan menghitung hasil keseluruhan dari nama dosen yang ingin dihitung.

\section{Activity Diagram}

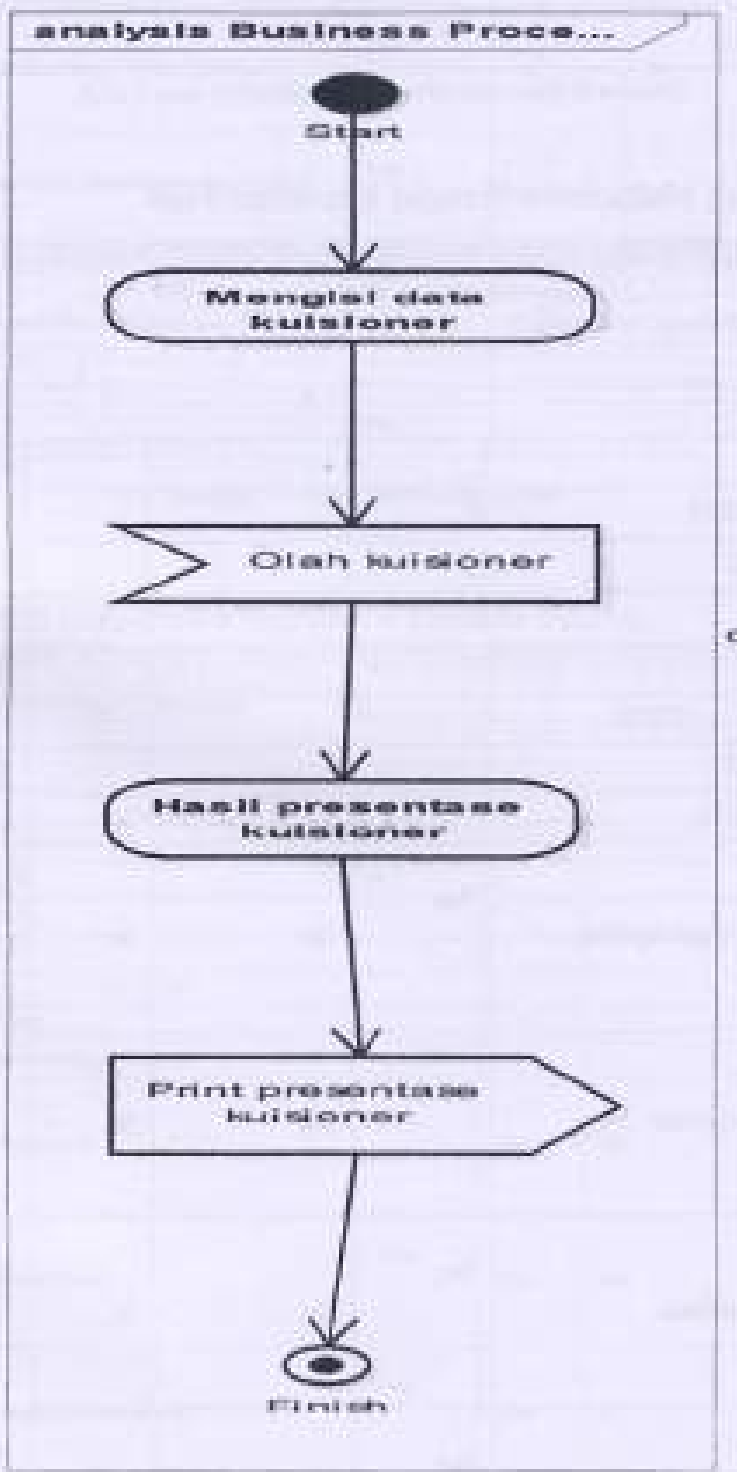

Ganther 5, Acmity Dugenam

Activity diogram menggambarkan berbagai flow (aliran) aktifitas dalam sistem yang sedang dirancang activity diagram juga dapat menggambarkan awalan suatu aktifitas, percabangan (decision) sampai pada tahap akhir suatu aktifitas sisterm.

Dari gambar diatas dapat kita lihat aktivitas program, pertama mahasiswa mengisi kuisioner, dan program akan mengolah kuisioner, setelah itu program akan meBampilkan presentase hasil dari nama dosen yang dihitung.

\subsubsection{Penerapan Fuzzy pada masalah penelitian}

Penerapan fazzy pada peagolahan data kuisioner evaluasi kinerja dosen dilakukan dengan mengolah bobot-bobot kuisioner menggunakan aturan fizzzy.

Metode fuczy yang digunakan adalah metode Tsukamoto,

Untuk menentukan kinerja seorang dosen dipengaruhi oleh 3 variabel yaitu: Fisik, Materi, Perilaku.

Dan untuk kinerja dosen terbagi 3 kategori yaitu: Baik, Cukup dan Buruk. Selanjutnya dapat dibuat grafik untuk nilai keanggotaan himpunan ficzy untuk setiap variabel pada setiap anteseden dan himpunan fuzzy untuk kinerja sebagai berikut:

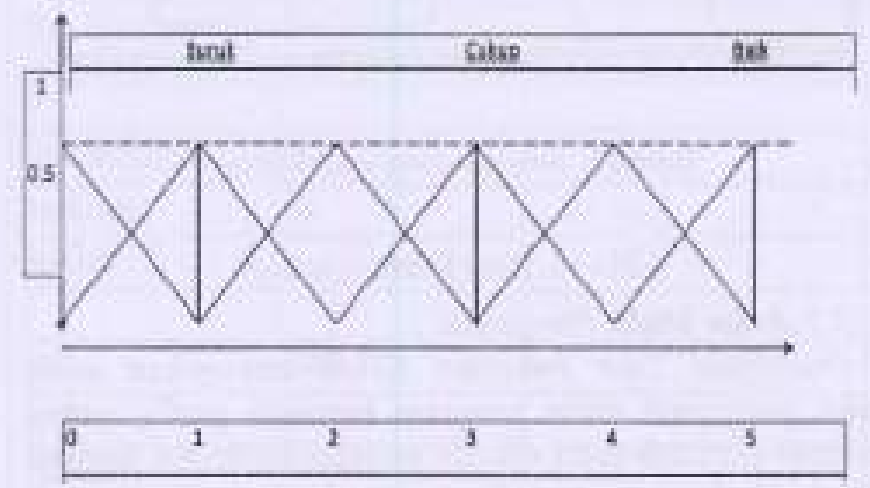

Gustar 6. Hioquana Fàny unsed setiop variabel pada setiap anteseden

Untuk mendapatkan nilai fuzzy, dilakukan langkahlangkah fuzzy dari nilai yang didapat dari kuisioner sebagai berikut:

\section{Membentuk fungsi keanggotaan}

Fungsi keanggotaan untuk setiap himpunan adalah:

a. Fungsi keanggotaan himpunan Buruk :

$$
\mu_{\sin }(x)=\left\{\begin{array}{lc}
\frac{x}{1} ; & 0 \leq x \leq 1 \\
\frac{2-x}{1}: & 1 \leq x \leq 2 \\
0 ; & x \geq 2
\end{array}\right.
$$

b. Fungsi keanggotaan himpunan Cukup: 
$\operatorname{\mu oM}(x)= \begin{cases}0: x \leq 2 \text { arau } x \geq 4 \\ \frac{x-2}{1} ; & 2 \leq x \leq 3 \\ \frac{4-x}{1}: & 3 \leq x \leq 4\end{cases}$

c. Fungsi keanggotaan himpunan Baik :
$\mu_{s M}(x)= \begin{cases}0= & x \leq 4 \\ \frac{x-4}{1}, & \leq x \leq 5\end{cases}$

Kinerja dosen terbagi menjadi 3 kategori, yaitu: baik, cukup dan buruk dapat digambarkan sebagai berikut:

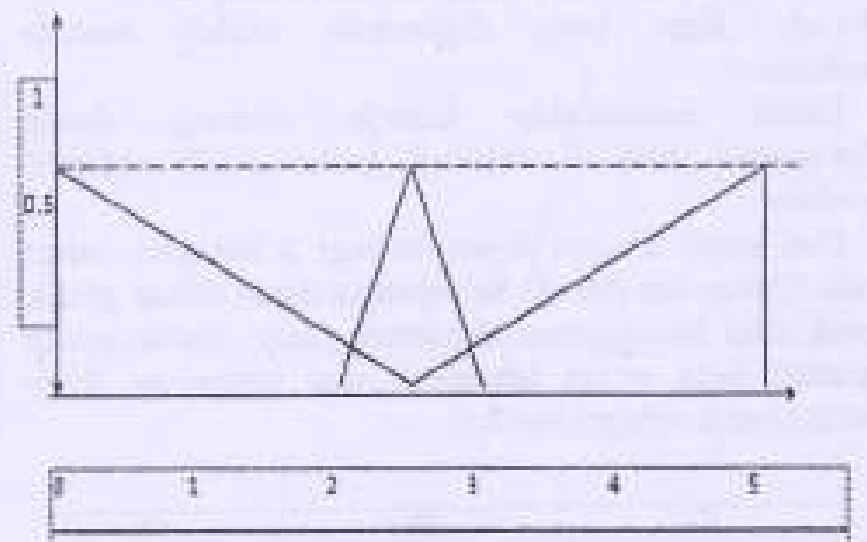

Gambar 7. Muquases Ficzy untak kitcrj:

\section{HASIL DAN PEMBAHASAN}

\section{I Antar Muka Pengguna}

Graphical User Interface (GUD) merupakan antar muka pengguna suatu program berbasis grafis, yakni perintah-perintah tidak diketik melalui keyboard, berikut adalah beberapa tampilan antar pengguna untuk berinteraksi dengan sistem.

\section{Form Mahasiswa, Memilih Kode Mata Kuliah}

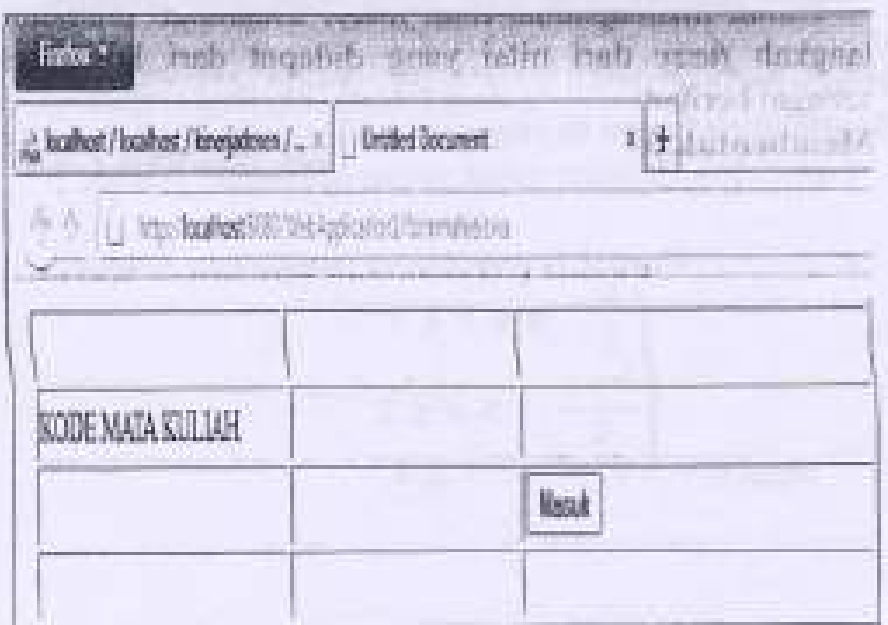

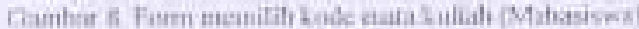

2.From tampilan setelah menilih kode mata kuliah

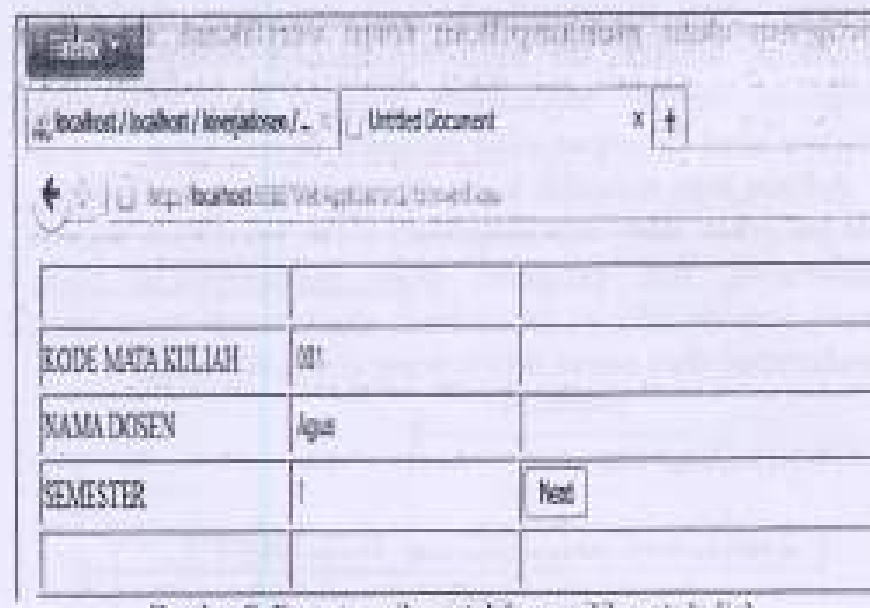

Gambar 9. Fom tampilias setelath memilith mata kutial

3.From Mahasiswa Mengisi Kuisioner Fisik

\begin{tabular}{|c|c|c|c|}
\hline 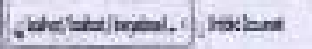 & & me int & \\
\hline 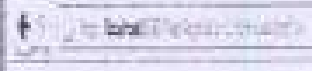 & & & $44=$ \\
\hline F & & & \\
\hline mevantes & a & & \\
\hline waxer & in & & \\
\hline Eest & i & & \\
\hline FENS & & & \\
\hline 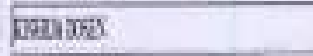 & & & \\
\hline haphitith & & & \\
\hline 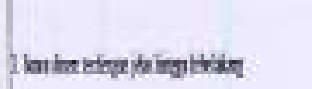 & $\operatorname{lng}$ & 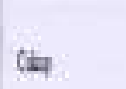 & is \\
\hline Masutingulas. & $\operatorname{lng}$ & (1) & It \\
\hline 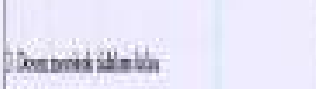 & Lent & lis & H \\
\hline 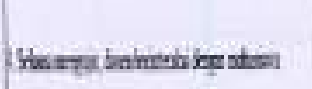 & $i n$ & $(t)$ & w \\
\hline 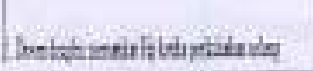 & iat & $=1$ & 1. \\
\hline
\end{tabular}

Ganthar 10, Fotm busuner frik 
4.From Mahasiswa Mengisi Kuisioner

\section{Materi}

\begin{tabular}{|c|c|c|c|}
\hline 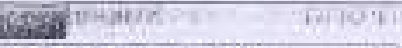 & $T^{2}$ & $\pi$ & $4=1$ \\
\hline 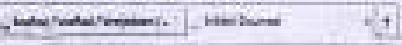 & & & \\
\hline$\pm=$ wor & & & $\because 4$ \\
\hline - & & & \\
\hline 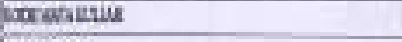 & F & & \\
\hline powisess & bo & & \\
\hline nems. & 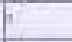 & & \\
\hline & & & \\
\hline rexpox & & & \\
\hline menas & & & \\
\hline Gracillation & & & \\
\hline 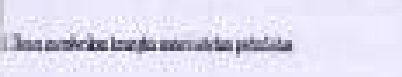 & $\ln =$ & $\mathrm{OHo}$ & lat \\
\hline 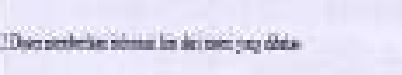 & $\ln$ & Gine & ht \\
\hline 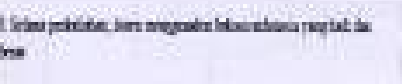 & $\mathrm{km}$ & 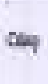 & 3 \\
\hline 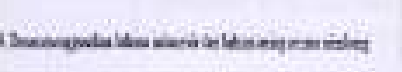 & 4 & an & 3a \\
\hline . & tand & a. & 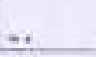 \\
\hline
\end{tabular}

Gamhar 11. Form kasisiuner maieri

5. Form Mahasiswa Mengisi Kuisioner Pelaku

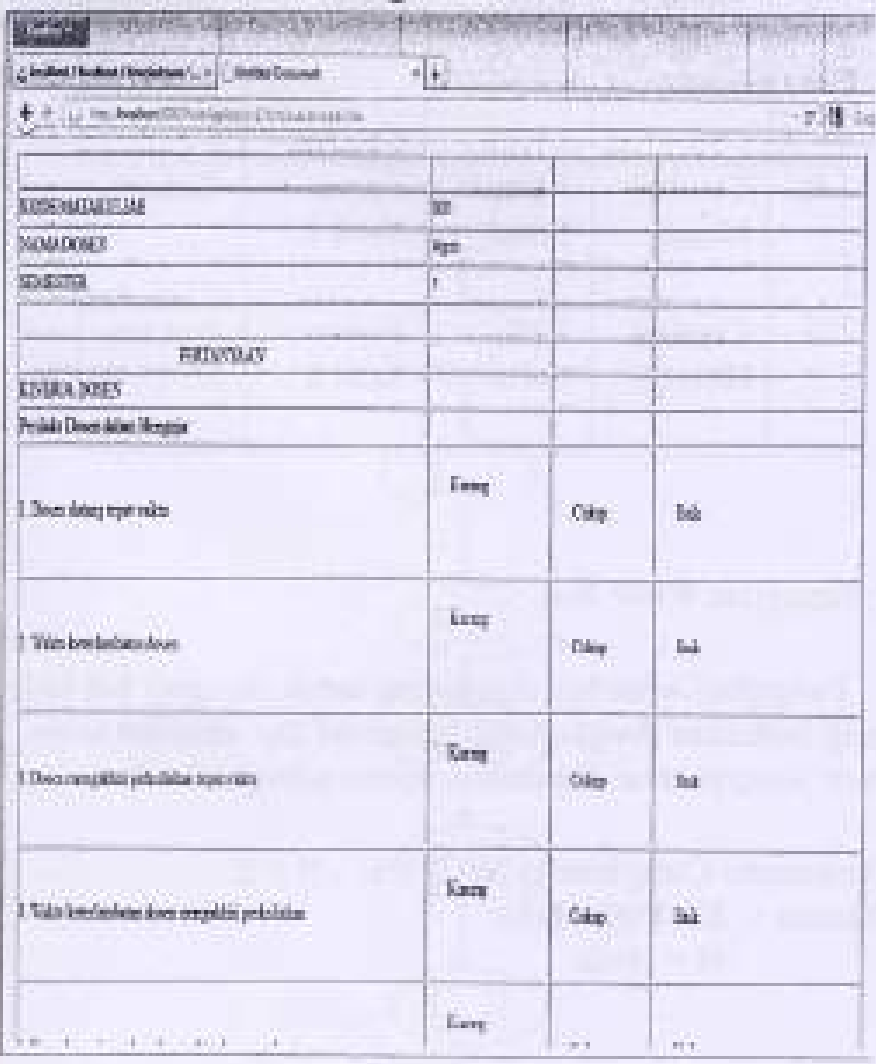

Cintwar 12 Furm kaisiuner perilake

6. Form Admin Memilih Kode Mata Kuliah

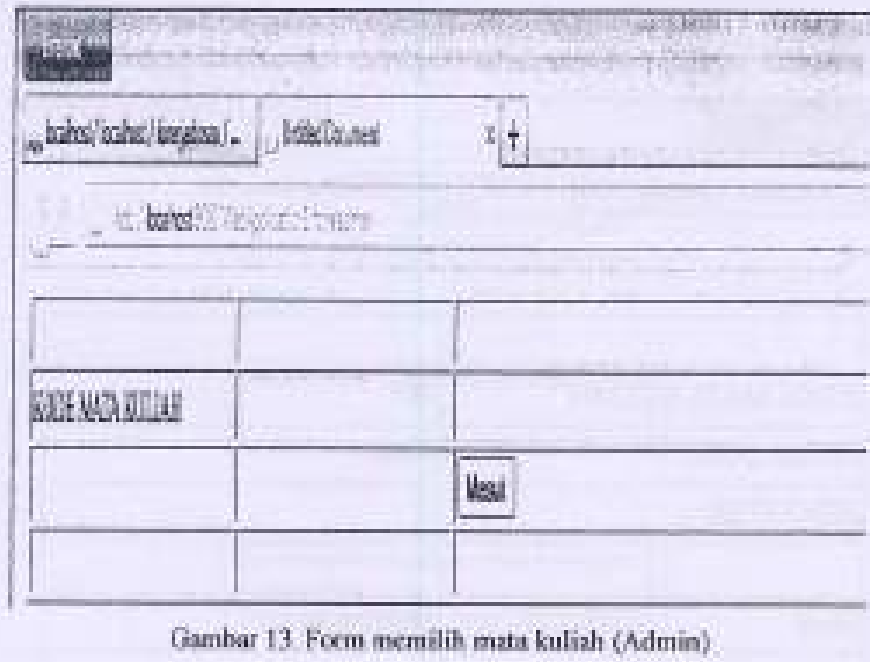

\section{Form Admin2}

\begin{tabular}{|c|c|c|}
\hline 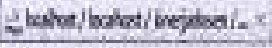 & 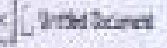 & $x+$ \\
\hline 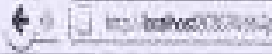 & istetotanume & \\
\hline 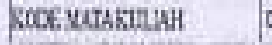 & $\omega$ & \\
\hline QHeA Xo5E & $\rightarrow$ & \\
\hline SEVETाR & 1 & \\
\hline 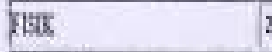 & $2 \pi 06$ & \\
\hline Meral & $2 \approx 5 \pi$ & \\
\hline PRILKT: & 25 & \\
\hline & & Feng \\
\hline
\end{tabular}

Garritar 14. Fom admin2 untuk menampitkan matikaliah y:ung fi pilih

\section{Form Hasil 1}

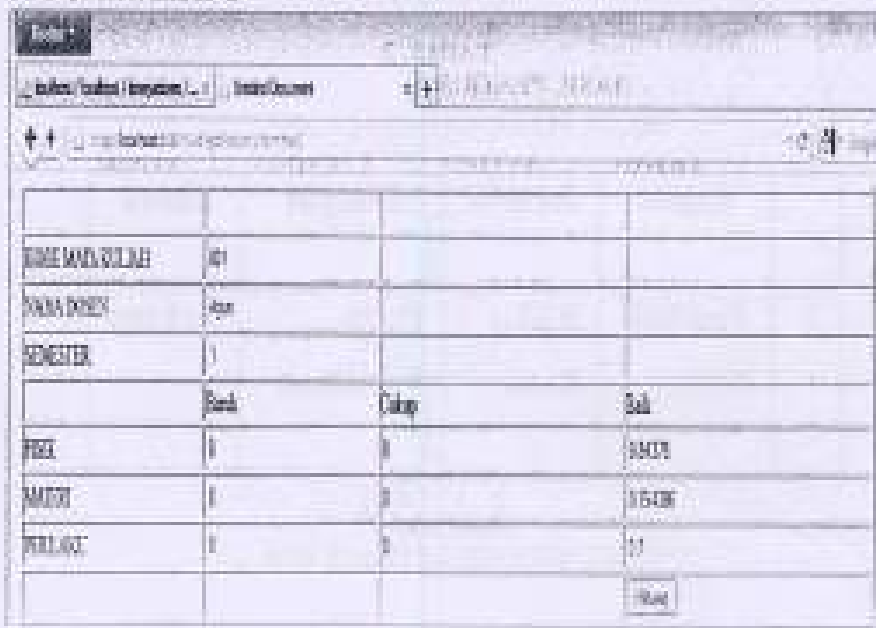




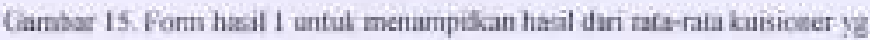
telab diisi

9. Form Hasil 2

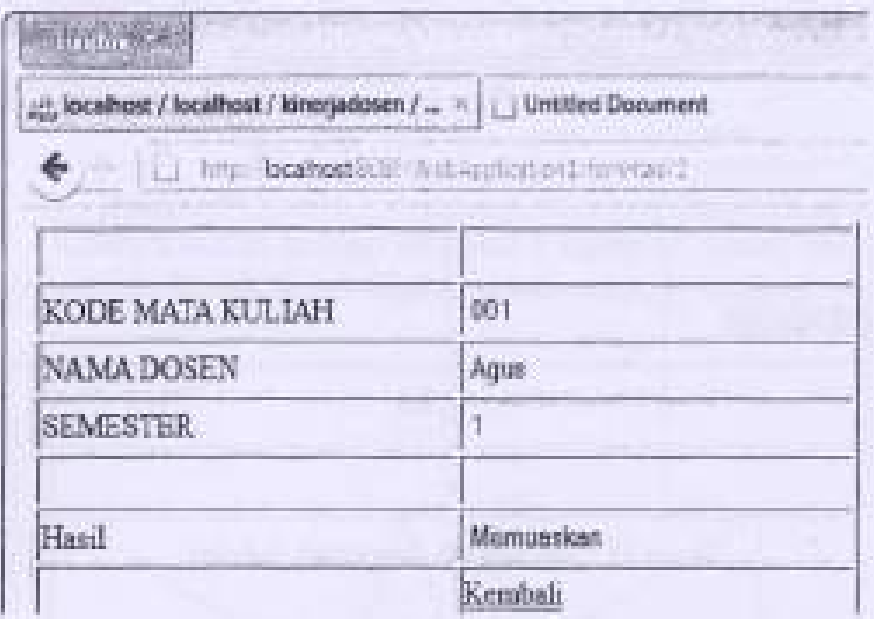

Gambar 16. Forn hesil 2 untuk menarpiltan hasi total

\subsection{Pengujian Aplikasi}

\section{Pengujian Black Bax}

Pengujian selanjutnya dilakukan untuk memastikan bahwa suatu event atau masukan akan menjalankan proses yang tepat dan menghasilkan output sesuai dengan rancangan. Untuk contoh pengujian terhadap beberapa perintah sebagai berikut :

Untuk Mahasiswa

TABEL 1.

HASE PENCUIHAN BUACK BOX

\begin{tabular}{|c|c|c|c|c|}
\hline & Input & Action & \multicolumn{1}{|c|}{ Output } & Hasil \\
\hline 1. & $\begin{array}{l}\text { Tombol } \\
\text { Masuk }\end{array}$ & $\begin{array}{l}\text { Klik, } \\
\text { Enter }\end{array}$ & $\begin{array}{l}\text { Form } \\
\text { mahasiswa }\end{array}$ & Sukses \\
\hline
\end{tabular}

TABEL 2

HASIL. PENGOJIAN BLACK BDX

\begin{tabular}{|l|l|l|l|l|}
\hline & Input & Aetion & Output & Hasil \\
\hline 1. & $\begin{array}{l}\text { Tombol } \\
\text { Next }\end{array}$ & $\begin{array}{l}\text { Klik, } \\
\text { Enter }\end{array}$ & $\begin{array}{l}\text { Form } \\
\text { Verifikasi }\end{array}$ & Sukses \\
\hline
\end{tabular}

TABEL 3

HLSIL PENGUIAN RL ICK MOX

\begin{tabular}{|l|l|l|l|l|}
\hline & Input & Action & Output & Hasil \\
\hline 1. & $\begin{array}{l}\text { Tombol } \\
\text { Simpan }\end{array}$ & $\begin{array}{l}\text { Klik, } \\
\text { Enter }\end{array}$ & $\begin{array}{l}\text { Form } \\
\text { Kuisioner } \\
\text { fisik }\end{array}$ & Sukses \\
\hline 2. & $\begin{array}{l}\text { Tombol } \\
\text { Simpan }\end{array}$ & $\begin{array}{l}\text { Klik, } \\
\text { Enter }\end{array}$ & $\begin{array}{l}\text { Form } \\
\text { Kuisioner } \\
\text { Materi }\end{array}$ & Sukses \\
\hline 3. & $\begin{array}{l}\text { Tombol } \\
\text { Simpan }\end{array}$ & $\begin{array}{l}\text { Klik, } \\
\text { Enter }\end{array}$ & $\begin{array}{l}\text { Form } \\
\text { Kuisioner } \\
\text { Perilaku }\end{array}$ & Sukses \\
\hline
\end{tabular}

Untuk admin

TABFL 4

HASIL PENGUIAN BLACK BOX

\begin{tabular}{|c|l|l|l|l|}
\hline & Input & Action & Output & Hasil \\
\hline 1. & $\begin{array}{l}\text { Tombol } \\
\text { Masuk }\end{array}$ & $\begin{array}{l}\text { Klik, } \\
\text { Enter }\end{array}$ & $\begin{array}{l}\text { Form } \\
\text { admin 2 }\end{array}$ & Sukses \\
\hline 2. & $\begin{array}{l}\text { Tombol } \\
\text { Hitung }\end{array}$ & $\begin{array}{l}\text { Klik, } \\
\text { Enter }\end{array}$ & $\begin{array}{l}\text { Form } \\
\text { hasil 1 }\end{array}$ & Sukses \\
\hline 3. & $\begin{array}{l}\text { Tombol } \\
\text { Hitung }\end{array}$ & $\begin{array}{l}\text { Klik, } \\
\text { Enter }\end{array}$ & $\begin{array}{l}\text { Form } \\
\text { hasil 2 }\end{array}$ & Sukses \\
\hline
\end{tabular}

\section{Pengujian White Box}

Pengujian whitebox digunakan untuk menguji hal-ha yang berkaitan dengan logika internal dan struktur kode Pada pengujian ini digunnkan rumus sebagai berikut :

Cyelomatic Complexcity $V(G)=E-N+2$

Dimana : $\quad E=$ Path $/$ Jalur

$$
\mathrm{N}=\text { Node }
$$


Berikut adalah pengujian whitebox pada aplikasi ini :

a. Flowchart Mahasiswa

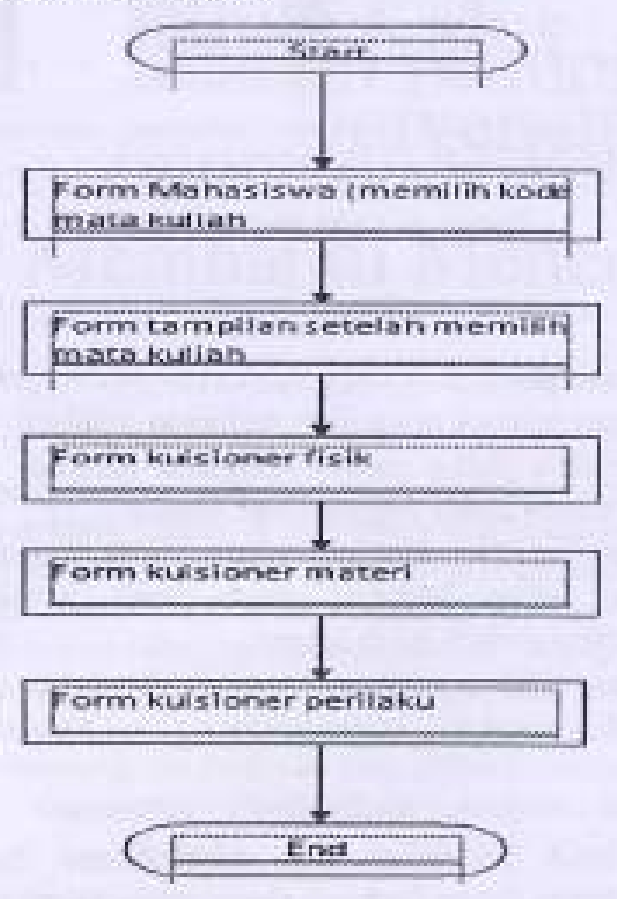

Gamhar 17. Flowchart aahasiswa

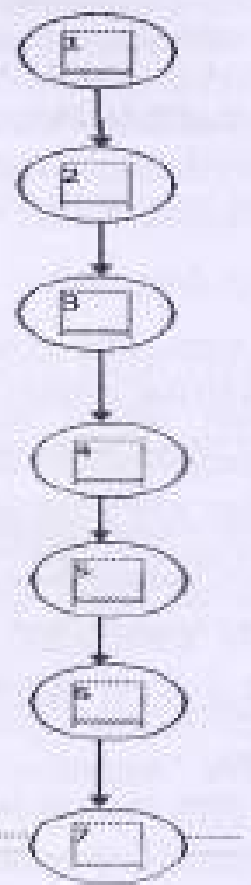

b. Flowchart Admin

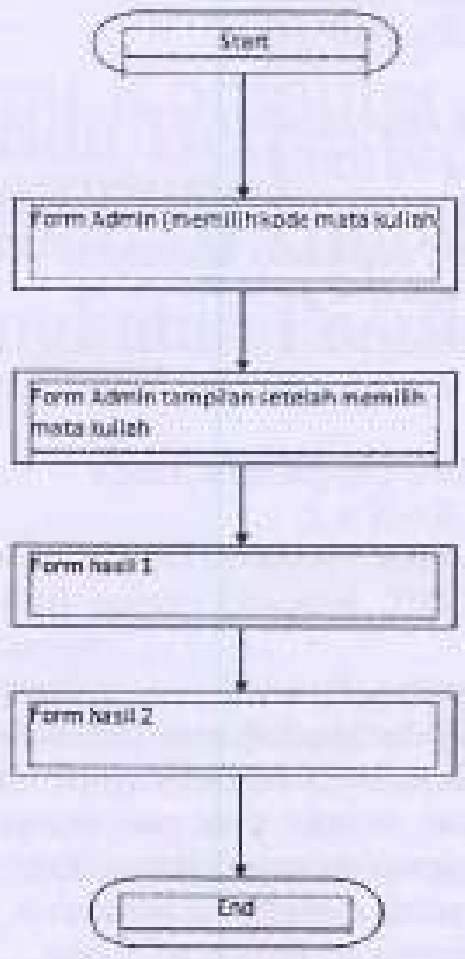

Gambar 19. Flowchart Admit

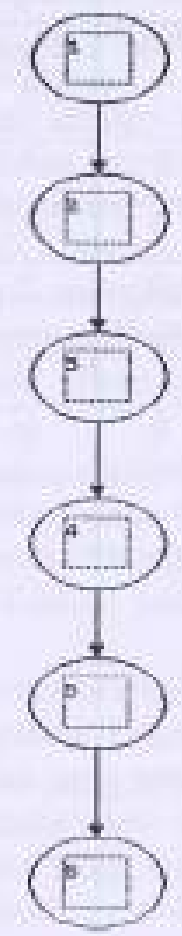


Gambar 20. Flowgraph Admin

c. Set path linier Mahasiswa

$1-2-3-4-5-6-7$

\section{Set path linier Admin}

$1-2-3-4-5-6$

d. Cyelomatic Complexcity Mahasiswa

$$
\begin{aligned}
& V(G)=E-N+2 \\
& V(G)=6-7+2 \\
& V(G)=1
\end{aligned}
$$

\section{Cyclomatic Complexcity Admin}

$V(G)=E-N+2$

$V(G)=5-6+2$

$V(G)=I$

\subsection{Implikasi Penelitian}

Penulis menyebarkan kuisioner perbandingan tingkat keakuratan kinerja dosen dalam mengajar berbasis fuzzy. survey dilakukan dengan cara menyebarkan kuisioner terhadap 6 orang mahasiswa, 2 dosen. Tujuan dilakukan survey adalah untuk mengetahui perubahan yang terjadi setelah dilakukannya implementasi sistem.

Berikut adalah hasil kuisioner beserta grafik hasil kuisioner :

TARFLS. HASUL NILAIKUISIONIER

\begin{tabular}{|c|c|c|c|c|c|}
\hline $\begin{array}{c}\text { Pertanyaan } \\
\text { No }\end{array}$ & $\begin{array}{c}\text { Poin } \\
1\end{array}$ & $\begin{array}{c}\text { Poin } \\
2\end{array}$ & $\begin{array}{c}\text { Poin } \\
3\end{array}$ & $\begin{array}{c}\text { Poin } \\
4\end{array}$ & $\begin{array}{c}\text { Poin } \\
5\end{array}$ \\
\hline 1 & 1 & 3 & 4 & 0 & 0 \\
\hline 2 & 0 & 0 & 3 & 4 & 1 \\
\hline 3 & 0 & 0 & 2 & 4 & 2 \\
\hline 4 & 0 & 1 & 3 & 2 & 2 \\
\hline 5 & 0 & 0 & 0 & 4 & 4 \\
\hline
\end{tabular}

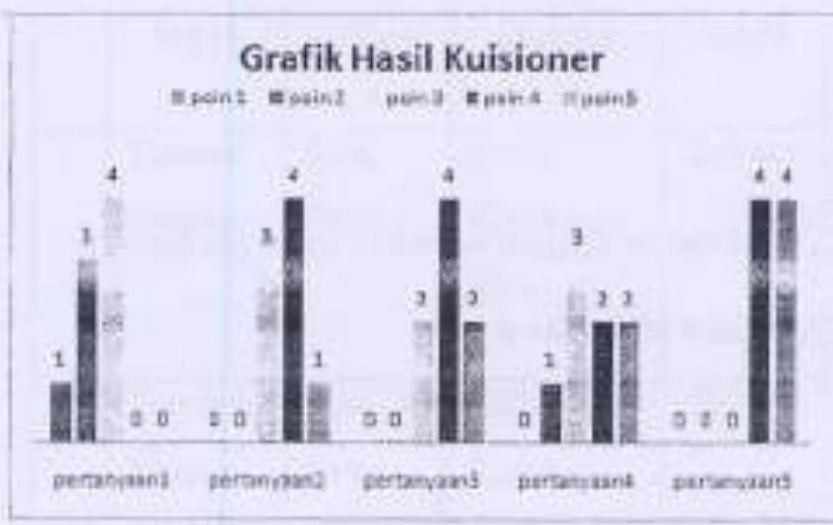

Gambar 21, Grafik Hzsil Kuisioner

\section{KESIMPUL.AN}

Dari hasil penelitiun yang dilakukan mulai dari tal perancangan hingga pengujian terhadap aplikasi kine dosen berbasis fuzzy untuk mengukur tingkat kine mengajar dosen maka disimpulkan bahwa :

1. Dengan dirancang dan diimplementasikanya aplik kinerja dosen berbasis fuezy hasil perhitung kuisioner menjadi lebih akurat.

2. Aplikasi ini adalah sebagai alat bantu un mengukur tingkat kinerja dosen

\section{SARAN}

Dari hasil penelitian dan pembahasan terhad aplikasi kinerja dosen berbasis fuzzy, maka saran yang usulkan adalah sebagai berikut:

1. Kembangkan aplikasi ini dengan tools lain j ada.

2. Buat report - nya.

\section{DAFTAR PUSTAKA}

[1]. Budiman. Deny 2010, Penerapan Neiro Fuzy unesk Metingka Akurssi Pengolahan Ketsioner Fvifuasi Kinerja Dosen. S7,M/RX , Saich biorta

[2] Mwhark, Roy 2009, SISTEM CERDAS BERBNSIS KONSEP FU: LOGIC UNTUK EVAUUASI KINERUA KARYAWAN. PT JUT Andrean Sslon das PT Takindo SelaksaAnagernh

[3]. (Undang- (Indang RI Na. 14 tentang Gint dat Dosen, 2005)

[4]. Kustoen, D, e. (2010). Pedaman Behan Kegja Dasen daw Eva

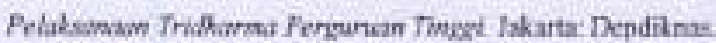

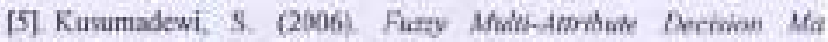
Yokyekarta: Graha flmu.

[6]. Dong. P., \&. Dai, F, (2009), Evalualiog foc Teatiag Quatity 5ese Furcy Neural Network: MEE Compunor Socteny, 112 